\title{
Fixed Drug Eruption in Children: a 24-Year, Single-center, Retrospective Cohort Study from Turkey
}

\section{Çocuklarda Görülen Fiks illaç Erüpsiyonu: Türkiye'den 24-Yıllık, Tek Merkezli, Retrospektif Bir Çalışma}

\author{
Goncagül Babuna Kobaner ${ }^{1}$ (D), Esen Özkaya ${ }^{1}$ (D) \\ ${ }^{1}$ istanbul University, İstanbul Faculty of Medicine, Department of Dermatology and Venereology, İstanbul, Turkey
}

ORCID ID: G.B.K. 0000-0002-0985-5027; E.Ö. 0000-0002-9585-9509

Citation/Attf: Babuna Kobaner G, Ozkaya E. Fixed drug eruption in children: a 24-year, single-center, retrospective cohort study from Turkey. Çocuk Dergisi - Journal of Child 2021;21(2):142-148. https://doi.org/10.26650/jchild.2021.925276

ABSTRACT

Objective: Fixed drug eruption (FDE), although a common type of drug eruption affecting all ages, has rarely been reported in children. This study aimed to investigate the characteristics of pediatric patients with FDE diagnosed in a tertiary referral center from Turkey.

Material and Methods: A single-center, retrospective cohort study based on the analysis of data of patients with an established diagnosis of FDE between 1996-2019, using standard forms prepared for the purpose of precise clinical documentation.

Results: The overall prevalence of pediatric FDE was $10.4 \%(n=22 / 212)$. Cotrimoxazole was the leading sensitizer before 2003, whereas nonsteroidal anti-inflammatory drugs (mainly naproxen) predominated thereafter. Phenobarbital in suppositories for fever was another important cause of pediatric FDE in younger children. The most frequently involved site was the trunk (68.2\%), followed by the lips (54.5\%), and extremities (45.5\%). Cotrimoxazole was the leading causative agent in every location, except for phenobarbital in perioral area. Oral mucosa was involved in $36.4 \%$ of the patients, mainly with multiple lesions involving inner lip mucosa (75.0\%). Its major morphological form was bullous/erosive (50.0\%). Genital mucosa was less commonly (31.8\%) involved. Among 9 children with cotrimoxazole-induced FDE, 5 (55.6\%) were positive for complete haplotype (HLA-A30 B13 Cw6) or separate antigens (HLA-A30 or HLA-Cw6), supporting a possible link between cotrimoxazole-induced FDE and HLA-A30.

Conclusion: This study showed that FDE is a common type of drug eruption in the pediatric population. Clinical findings, drug-specific site involvement, and most common inducers of FDE in children seem to be largely similar to those in adults.

Keywords: Children, cotrimoxazole, fixed drug eruption, non-steroidal anti-inflammatory drugs, naproxen, pediatric
ÖZ

Amaç: Fiks ilaç erüpsiyonu (FiE), sık görülen ve her yaşı etkileyebilen bir ilaç döküntüsü olmasına rağmen çocuklarda nadiren bildirilmiştir. Çalışmamızda, Türkiye'de üçüncü basamak bir referans merkezde FiE tanısı konulmuş olan pediatrik hastaların karakteristik özelliklerinin değerlendirilmesi amaçlanmıştır.

Gereç ve Yöntem: Bu tek-merkezli, retrospektif kohort çalışması, kliniğimizde 1996-2019 yılları arasında Fí tanısı konularak takip ve tedavi edilen çocuk hastaların, standart olarak hazırlanmış hasta takip formlarındaki verilerinin analiz edilmesiyle gerçekleştirilmiştir.

Bulgular: Çalışmamızda pediatrik FiE'nin genel prevalansı \%10,4 ( $n=22 / 212$ ) olarak bulundu. Çocuklarda FiE'nin en sık nedeni 2003 yılından önce kotrimoksazol iken daha sonraki yıllarda non-steroidal antienflamatuvar ilaçlar (özellikle naproksen) ön plandaydı. Ateş düşürücü supozituvarlar içinde bulunan fenobarbital de özellikle küçük çocuklarda FiE'nin bir diğer önemli nedeniydi. Çocuklarda en çok tutulan alanlar sırasıyla gövde $(\% 68,2)$, dudaklar $(\% 54,5)$ ve ekstremiteler $(\% 45,5)$ olarak bulundu. Hemen her bölgede FiE'nin en sık nedeni kotrimoksazol iken, perioral bölgede fenobarbitaldi. Çocukların \%36,4'ünde oral mukoza tutulumu görüldü. Oral mukoza lezyonları genellikle multiple olup iç dudak mukozasını tutmaktaydı $(\% 75,0)$ ve en sık görülen morfolojik formu büllöz/erozif $(50,0 \%)$ idi. Çocuklarda genital mukoza tutulumuna daha nadir $(\% 31,8)$ rastlandı. Kotrimoksazole-bağlı FiE'si olan ve HLA tiplendirilmesi yapılan 9 çocuktan 5 'inde $(\% 55,6)$ komplet haplotip (HLAA30 B13 Cw6) veya tek başına antijen (HLA-A30 veya HLA-Cw6) pozitiflikleri saptandı. Bu bulgu, kotrimoksazole bağlı FiE ile HLA-A30 arasında potansiyel bir ilişki olduğunu destekler nitelikteydi.

Sonuç: Çalışmamız, FiE'nin pediatrik yaş grubunda sık görülen bir ilaç erüpsiyonu olduğunu ortaya koymuştur. Ayrıca, çocuklarda görülen FiE'nin, klinik bulgular, ilaca-spesifik bölge tutulumu ve en sık neden olan ilaçlar açısından erişkinlerde görülen FiE'ye büyük ölçüde benzerlik gösterdiği saptanmıştır.

Anahtar Kelimeler: Çocuklar, fiks ilaç erüpsiyonu, kotrimoksazol, nonsteroidal antienflamatuvar ilaçlar, naproksen, pediatrik

Corresponding Author/Sorumlu Yazar: Esen Özkaya E-mail: profeo@istanbul.edu.tr Submitted/Başvuru: 21.04.2021 • Accepted/Kabul: 03.08.2021 


\section{INTRODUCTION}

Fixed drug eruption (FDE) is defined as the recurrence of sitespecific lesions on the skin and/or mucosa, after each intake of the responsible drug (1-3). Its classical clinical presentation includes round or oval-shaped, well-demarcated, red-to-livid, single or multiple plaques typically healing with residual pigmentation. Albeit rarely, it may also present with atypical clinical forms. FDE is a type IVc (delayed-type) immune reaction in which cytotoxic T cells play a pivotal role (1). The gold standard for diagnosing FDE is systemic provocation, while topical provocation testing offers a safer alternative method, and histopathologic examination helps to confirm the diagnosis (1). The drugs responsible for causing FDE change over time and from country to country (4). Turkey is one of the countries with a relatively high share of FDE cases in the literature (4-6).

Since its first description in the late 1800s, FDE has been reported in both genders and at any age (1). However, there are only few studies specifically focusing on FDE in the pediatric population (7-9). Yet, dermatologists and pediatricians should be familiar with this lesser-known and underreported drug eruption in children as it can easily be misdiagnosed without a high index of clinical suspicion.

The present study aimed to evaluate the characteristic features of FDE in pediatric patients who were diagnosed over a long period of time in a tertiary referral center in Turkey. Moreover, the main similarities and differences of FDE between children and adults were discussed with a particular emphasis on clinical findings, drug-specific site involvement, and the causative drugs.

\section{MATERIAL AND METHODS}

This was a single-center, retrospective cohort study conducted on patients with $\mathrm{FDE}$, who were diagnosed and registered in our allergy unit between 1996 and 2019. Out of 212 patients with a definite diagnosis of FDE that was confirmed by oral provocation tests or by therapeutic re-exposure to the drug $(1,10), 22$ patients who were in the pediatric age group $(\leq 18$ years) were enrolled in the study. This study was approved by the Ethical Committee of Istanbul University, Istanbul Faculty of Medicine (approval number: 2021/93) and conducted in accordance with the Declaration of Helsinki.

Provocation tests were performed in the remission period of $\mathrm{FDE}$, and after obtaining verbal or written consent from the legal guardian of the children. Patients were asked not to take antihistamines/non-steroidal anti-inflammatory drugs (NSAIDs)/immunosuppressive drugs, and not to use topical or systemic corticosteroids as well as the suspected drug for at least 1 month before and during the provocation tests. Oral provocation testing was started with a subtherapeutic initial dose of a certain drug, such as $1 / 8$ of a tablet. It was then increased to $1 / 4,1 / 2$, and one full dose at 12 - to 24 -hour intervals. Reactivation of the old FDE sites with marked erythema and/ or edema and coexisting itching and/or burning sensation that started between 10-30 minutes and up to a few hours after taking the graded doses of the suspected drug was regarded as a positive test result (1). For the topical provocation test, the suspected drugs were usually applied at concentrations of $1-10 \%$ in white petrolatum/water or dimethyl sulfoxide (when testing with cotrimoxazole) to the old FDE sites as occlusive or open patch testing $(1,11)$. The test was considered positive if erythema and/or induration developed in an old FDE lesion within 24 hours and persisted there for at least 6 hours (1).

Patient's files were evaluated with regard to demographic, clinical, and histopathological features, the causative drugs and their temporal change during the study period, and the presence of HLA A30 B13 Cw6 haplotype as well as the presence of HLA-B55 antigen (split of B22) which had previously been identified as genetic markers for cotrimoxazole-induced FDE (11). Class I HLA typing was performed by lymphocytotoxicity assay.

\section{Statistical analysis}

Data were stored and assessed using IBM SPSS ${ }^{\circ}$ Statistics Version 22. Quantitative data were presented as means \pm standard deviation (SD) and qualitative data as number (n) and percentage (\%). The chi-square or Fisher's exact test was used to compare frequencies. A 2-tailed $P$-value $<0.05$ was regarded as a statistically significant difference.

\section{RESULTS}

The overall prevalence of pediatric FDE was 10.4\% (22/212). The male to female ratio was $1: 1.8$, and the age range was 2-18 years. The main characteristics of 22 pediatric patients with FDE are shown in Table 1.

Atopy was observed in $2(9.1 \%)$ patients, both of whom had allergic rhinoconjunctivitis. None of the patients had a family history of FDE.

One patient had his first attack, whereas 4 patients had more than 10 attacks at the time of diagnosis. Itching and burning were the major symptoms.

The causative drug was confirmed by oral provocation test in 15 patients (68.2\%) and by therapeutic exposure of a single specific drug in 7 patients (31.8\%). FDE in children was most frequently induced by cotrimoxazole $(n=11,50.0 \%)$, followed by nonsteroidal anti-inflammatory drugs $(n=7,31.8 \%)$ comprising naproxen $(n=4)$, piroxicam $(n=2)$, nimesulide $(n=1)$, and other, i.e., phenobarbital $(n=2)$, paracetamol $(n=1)$, and dimenhydrinate $(n=1)$. Cotrimoxazole was the main inducer between 1996-2002, whereas NSAIDs predominated between 2003-2019. No new cases of cotrimoxazole-induced FDE have been observed since 2012 .

Cotrimoxazole-induced FDE was most frequently seen among boys (62.5\%), and in patients younger than 10 years, whereas NSAID-induced FDE was more frequent among girls (71.4\%), and in those older than 10 years (85.7\%). The differences were statistically not significant.

The main reason in the present study for taking cotrimoxazole was upper respiratory tract infections, whereas dysmenorrhea 
Table 1. Characteristics of pediatric patients with the diagnosis of fixed drug eruption (FDE)

\begin{tabular}{|c|c|}
\hline Characteristic features & Patients with the diagnosis of FDE ( $n=22)$ \\
\hline Gender, male/female, $\mathrm{n}$ (ratio) & $8 / 14(1: 1.8)$ \\
\hline Age range, years (median) & 2-18 (13) \\
\hline Atopy (n) & None $(n=20)$, allergic rhinoconjunctivitis $(n=2)$ \\
\hline Overall prevalence of pediatric FDE (n) & $10.4 \%(22 / 212)$ \\
\hline Duration of the disease until the diagnosis of FDE, month (median) & $2-36(6.5)$ \\
\hline Topical provocation test $(\mathrm{n})$ & Not performed (14), positive (2), negative (6) \\
\hline Histopathology (n) & $\begin{array}{l}\text { Not performed (16), consistent with FDE (6) showing an interface } \\
\text { dermatitis characterized by dyskeratosis, basal cell vacuolar } \\
\text { degeneration, melanophages in the upper dermis, and perivascular } \\
\text { mononuclear inflammatory infiltration }\end{array}$ \\
\hline Number of attacks, range (median) & $1-10(4)$ \\
\hline Reactivation of lesions following the intake of the responsible drug, range & 10 minutes- 12 hours \\
\hline Number of lesions, range & 1-more than 50 (generalized) \\
\hline $\begin{array}{l}\text { Increase in the number and/or size of the lesions with subsequent } \\
\text { attacks ( } n \text { ) }\end{array}$ & Yes (12), no (10) \\
\hline
\end{tabular}

Additional mucosal involvement with subsequent attacks (n)

No (20), yes (2)

Causative drug (n)

Main causative drug according to time periods ( $n$ )

Cotrimoxazole (11), naproxen (4), piroxicam (2), phenobarbital (2), paracetamol (1), nimesulide (1), dimenhydrinate (1)

1996-2002: cotrimoxazole $(9 / 12=75.0 \%)$

2003-2019: non steroidal anti-inflammatory drugs (5/10 = 50.0\%)

Presence of HLA-A30 B13 Cw16 haplotype and HLA-B55 in

cotrimoxazole-induced FDE $(n=11)$

Negative (3), complete haplotype (2), A30 (2), Cw6 and B55 (1), B55 (1), not performed (2)

Reason for taking the causative drug $(n)$

Upper respiratory tract infection (10) (cotrimoxazole [9] and paracetamol [1])

Dysmenorrhea (4) (naproxen [2], piroxicam [2])

Fever (3) (phenobarbital [2], nimesulide [1])

Motion sickness (1) (dimenhydrinate)

Acne vulgaris (1) (cotrimoxazole)

Headache (1) (naproxen)

Not defined (2)

Prior diagnosis (n)

Herpes simplex labialis (4), recurrent aphthous stomatitis/Behçet's

disease (3), purpura (1), drug eruption (1), not defined (13)

Main symptom (n)

Itching and burning (15), itching only (4), not defined (2), no symptoms (1)

Localization of FDE ( $n)$

Skin only (12), skin\&mucosa (9), mucosa only (1)

Skin involvement $(n=21)$, gender $(n)$, causative drugs $(n)$

$\mathrm{F}(8)$ / M (13), cotrimoxazole (11) / naproxen (3) / piroxicam (2) /

phenobarbital (2) / other (3)

Characteristic of skin lesions $(n=21)$

* Localization (n) and causative drug (n)

Trunk (15) by cotrimoxazole (9) / naproxen (2) / other (4)

Lips (12) by cotrimoxazole (5) / naproxen (3) / piroxicam (2) / other (2)

Extremity (10) by cotrimoxazole (7) / other (3)

Hands (6) by cotrimoxazole (5), other (1)

Perioral (3), eyelid (3), other (7)

Number of lesions ( $n$ )

Morphology (n)

Solitary (1), 2-10 (14), 10-20 (4), generalized (2)

Typical solitary/mutiple plaques (20), grouped plaque (1)

Skin surface changes $(n)$

Residual hyperpigmentation ( $n$ )

Specific pattern ( $\mathrm{n})$

Bullae (6), pustules (1)

Yes (20), no (1)

Vermillon border (8), vermillon border+finger webs (2), vermillon

border+earlobe (1), finger webs (1), perioral (2), perioral\&periorbital (1),

nasal philtrum (1), grouped (1)

Mainly induced by (n)

Vermillon border by cotrimoxazole (5/11) and naproxen (2/11), finger webs exclusively by cotrimoxazole (3/3), perioral by phenobarbital (2/3)

Mucosal involvement $(n=10)$, gender $(n)$, causative drugs $(n)$

**Orogenital mucosa (5), F (4) / M (1), cotrimoxazole (3) / naproxen (2)

Oral mucosa only (3), F (3), cotrimoxazole (1) / piroxicam (1) /

phenobarbital (1)

Genital mucosa only (2), M (2), cotrimoxazole (1) / nimesulide (1)

Characteristics of oral mucosal lesions $(n=8)$

Localization (n)

Inner lip (2), inner lip\&gingiva (2), inner lip \&buccal (1), inner lip\&hard palate\&tongue (1), dorsum of the tongue (1), hard palate (1) Solitary (2, on the tongue and hard palate), 2-10 (4), $\geq 10$ (2)

Number of lesions ( $n$ )

Morphology ( $n$ ) Bullous/erosive (4), aphthous (2), erosive-aphthous (1), erythematous (1)

Lip lesions regarding skin and/or mucosal involvement (n)

Lip skin only (7), lip skin \& adjacent inner lip mucosa (5), inner lip mucosa only (1)

*The total number is $>21$ as more than one skin site was involved in most of the patients. ${ }^{* *}$ One patient with orogenital mucosal involvement showed additional

involvement of anal, nasal and conjunctival mucosa. F: female, M: male 
was the most common reason for the intake of NSAIDs. Phenobarbital in suppositories for fever was another important cause of FDE in younger children.

Eight patients were referred to our clinic with prior clinical diagnoses including "herpes simplex infection" $(n=4)$ in those with lip lesions, "recurrent aphthous stomatitis/Behçet's disease" $(n=3)$ in those with aphthous mucosal lesions, and purpura $(n=1)$.

The number of FDE lesions ranged between 1 and more than 50. Two patients $(9.1 \%)$ had generalized involvement. Twelve patients (54.6\%) had only skin lesions, whereas 9 (40.9\%) patients had both skin and mucosal lesions, and one patient $(4.5 \%)$ had mucosal lesions only. Mucosa was involved after the first FDE attack in 8 (36.4\%) patients, whereas 2 (9.1\%) patients had developed mucosal lesions subsequently. Twelve patients (54.5\%) reported an increase in the number and/or size of the lesions during subsequent attacks.

Skin lesions were mainly located on the trunk $(n=15)$, lips $(n=12)$, extremities $(n=10)$, hands $(n=6)$, and other. Cotrimoxazole was the leading causative agent in almost every location. Formation of bullae $(n=6)$ and pustules ( $n=1)$ (Figure 1 ) were occasionally observed as surface changes on skin lesions. Skin lesions healed leaving residual hyperpigmentation (Figure 2 ) in almost every patient ( $n=21)$. Specific patterns of skin lesions were observed, i.e., FDE on lips mainly involving the vermillion border $(n=11)$ (Figures 1 and 3 ) due to cotrimoxazole $(n=5)$, naproxen $(n=2)$, and other causes; FDE involving the finger webs $(n=3)$ exclusively from cotrimoxazole; and perioral FDE $(n=3)$ mainly induced by phenobarbital $(n=2)$.

Oral and genital mucosa was simultaneously involved in 5 patients, followed by oral mucosa only $(n=3)$, and genital mucosa only $(n=2)$. Mucosal FDE, especially oral mucosal lesions were predominantly seen in girls $(n=7,70.0 \%)$. On the other hand, both patients with isolated genital mucosal lesions were boys. Cotrimoxazole was the main causative agent $(n=5$, $50.0 \%)$ in mucosal FDE, followed by naproxen $(n=2,20.0 \%)$, and

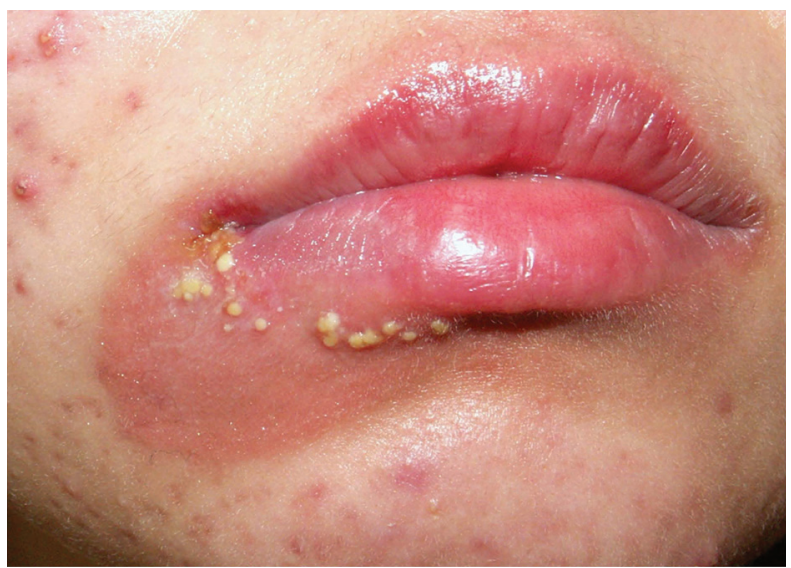

Figure 1: Fixed drug eruption (FDE) on the vermillion border of the lip showing pustules on the surface in a patient who was taking cotrimoxazole for the treatment of her acne vulgaris. other drugs. There was no statistically significant difference between cotrimoxazole and naproxen regarding oral or genital mucosal involvement.

The morphological forms of oral mucosal FDE comprised bullous/erosive $(n=4)$, aphthous $(n=2)$, erosive-aphthous $(n=1)$, and erythematous $(n=1)$. The inner lip mucosa was

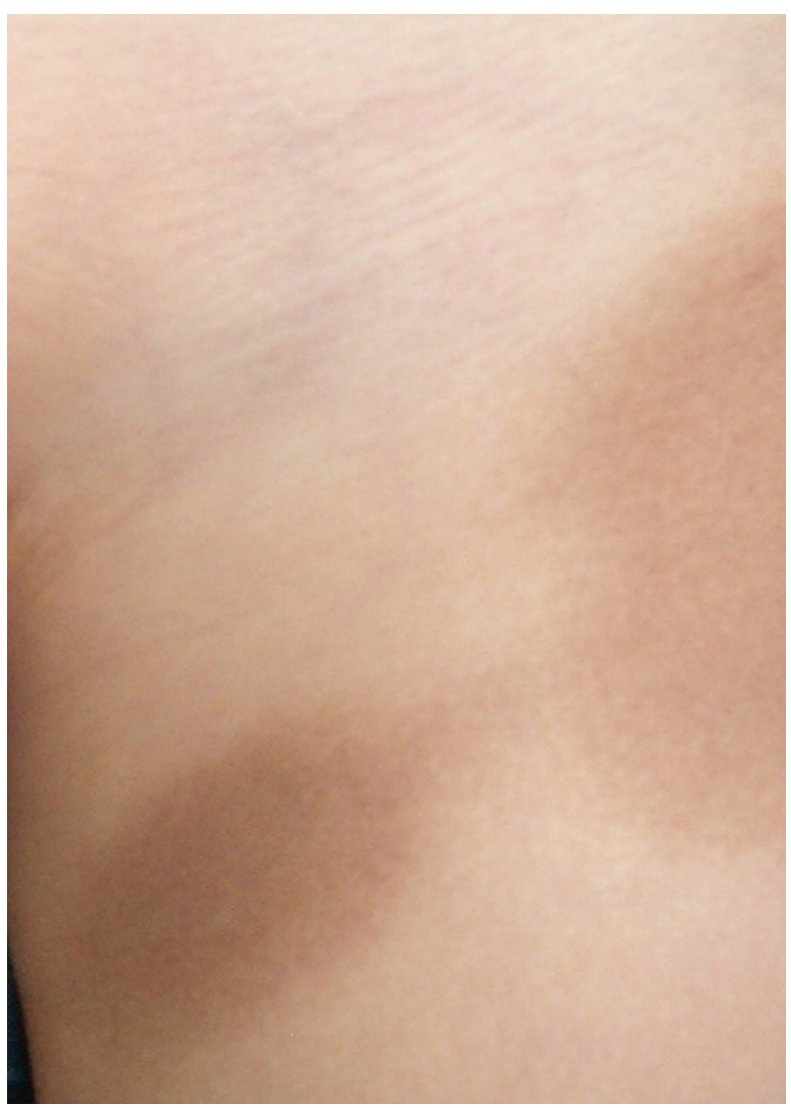

Figure 2: Old FDE sites on the inner thigh of a patient with cotrimoxazole-induced FDE showing residual hyperpigmentation.

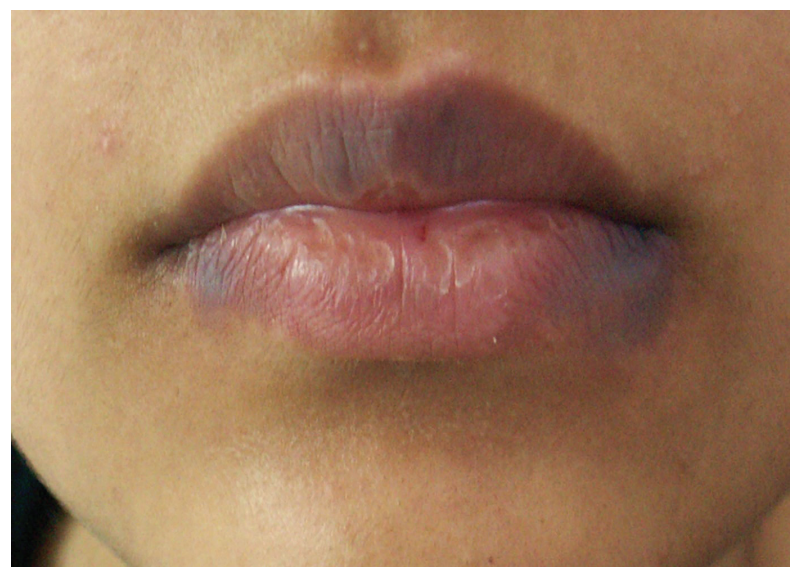

Figure 3: Old FDE sites on the vermillion border of the lips in a patient with naproxen-induced FDE showing residual hyperpigmentation. 
most frequently $(6 / 8,75.0 \%)$ involved. It accompanied adjacent lip skin lesions in 5 of 12 patients (41.7\%). Two patients had bullous/erosive type FDE on the hard palate due to NSAIDs (naproxen and piroxicam), and one patient erythematous type FDE on the dorsum of the tongue due to cotrimoxazole.

In 9 patients with cotrimoxazole-induced FDE, Class I HLA typing was performed. Among them, HLA-A30 B13 Cw6 was present as a complete haplotype in 2 patients, whereas HLA-A30 antigen was present in 2, and HLA-Cw6 antigen in 1 patient separately. Additionally, HLA-B55 (split of B22) antigen was positive in 2 patients.

\section{DISCUSSION}

The characteristic features of FDE have rarely been studied in children as most of the studies have been conducted on heterogenous groups of adult and pediatric patients. Our current knowledge of epidemiology, clinical aspects, and causative drugs of pediatric FDE is mainly based on case reports and a few clinical studies. However, FDE is not rare in children and has been reported to account for $14.4 \%$ and $22.0 \%$ of all cutaneous drug eruptions in this age group $(12,13)$. The overall prevalence of pediatric FDE was $10.4 \%$ in our large series of patients, supporting the importance of FDE as a common type of drug eruption in children.

Most patients (63.6\%) were girls in the present study, although previous studies revealed a predominance of boys in pediatric FDE $(7,8)$. Nevertheless, no gender preference has been documented in the majority of studies evaluating FDE patients of all ages $(2,3,5,14)$. On the other hand, more than half $(59.1 \%)$ of the patients were adolescents in this pediatric cohort. None of the patients were younger than 1-year-old, although FDE may affect all age groups, even infants $(15,16)$.

In children, FDE has been reported to occur anywhere on the body including on the skin and/or mucosa $(7,8)$. In the present series, the most frequently involved site was the trunk (68.2\%), followed by the lips (54.5\%), in particular, the vermillion border, and extremities (45.5\%) including finger webs. In a previous study carried out at our clinic evaluating 105 adult and pediatric patients, FDE was most commonly located on the genital mucosa (50.5\%), followed by the trunk (38.1\%), and lips (37.1) (5).

Considering these data, the favored sites of FDE in children seem to be largely similar to those in adults (5). However, genital mucosa was less commonly involved $(31.8 \%)$ in pediatric patients.

There is a long list of medications implicated in the development of FDE. The culprit drugs change over time, and from country to country, reflecting local prescribing habits in a given time frame (1-3). So far, only a few studies have investigated the causative drugs of FDE in children. Acetylsalicylic acid and hyoscine butyl bromide, and cotrimoxazole and acetaminophen (paracetamol) were reported as the most common causes of pediatric FDE in a study from Libya (7) and a multinational study (8), respectively.
In the present cohort, however, the main inducers of pediatric FDE were cotrimoxazole and NSAIDs accounting for more than $3 / 4$ of all cases in children. Cotrimoxazole was the leading sensitizer between 1996 and 2002, whereas NSAIDs (mainly naproxen) predominated between 2003 and 2019. A previous study from our clinic evaluated changing trends in inducer drugs of FDE over time (between 1996 and 2016) among 191 adult and pediatric patients (4). In the earlier years of that study, cotrimoxazole was the most common cause of FDE, which was replaced by naproxen in 2000 (4). The decreasing incidence of cotrimoxazole-induced FDE in the present and previous studies can be explained by the dramatic drop in cotrimoxazole use in our country after the beginning of the 2000s (4). On the other hand, the high incidence of NSAID-induced FDE represents the increasing use of this drug class in children, particularly for the management of dysmenorrhea in adolescent girls. In addition to cotrimoxazole and NSAIDs, phenobarbital in suppositories for fever (9.1\%) was another important cause of FDE in younger children. This was a striking difference between children and adults, as the overall prevalence of phenobarbital-induced FDE was only around $1 \%$ among all FDE patients at our clinic (10).

In this study, cotrimoxazole was the leading cause of pediatric FDE in almost every location. FDEs on the vermillion border $(n=11)$ and finger webs $(n=3)$ were mainly induced by cotrimoxazole. NSAIDs (41.7\%) were another important inducer in lip involvement. In a previous study from our clinic including mainly adults, NSAIDs (naproxen and oxicams) were the most common causative drugs of FDE on lips (5). Moreover, phenobarbital (66.7\%) was the main inducer of perioral FDE in children, which is an interesting finding that has not previously been observed in our adult patients.

Cotrimoxazole (57.1\%) was the main cause of genital FDE in this pediatric cohort as well as in a previous study from our clinic including mainly adults (5). NSAIDs (42.9\%) were responsible for the remaining cases in children. On the other hand, in a study from Israel evaluating 15 boys with genital FDE, hydroxyzine, cotrimoxazole, and acetaminophen were reported as the most common causative drugs (9). Interestingly, none of the cases in our pediatric cohort were induced by antihistamines, despite their broad use in Turkey.

Oral mucosal FDE was seen in $36.4 \%$ of our pediatric patients, most of them being girls. Its major morphological form was bullous/erosive (50.0\%), while other forms (aphthous, erosiveaphthous, and erythematous) were less commonly observed. A majority of the patients had multiple lesions mainly involving the inner lip mucosa (75.0\%), while 2 patients had solitary lesions located on the tongue and hard palate, respectively. Cotrimoxazole (50.0\%) was the main causative agent, followed by naproxen (25.0\%). A previous study from our clinic which was conducted on 61 adults and pediatric patients revealed similar findings with regard to the prevalence, localization, and morphology of oral mucosal FDE (6). However, naproxen $(49.2 \%)$ was the main inducer in that study, followed by cotrimoxazole (37.7\%). 
Although the pathogenesis of FDE is still elusive, familial cases with pyrazolone-induced FDE have raised the possibility of a genetic predisposition to this specific type of drug eruption (17). Moreover, a highly significant association has been reported between an HLA class I antigen (HLA-B22) and feprazone (a pyrazolone derivative)-induced FDE in the literature (18). A previous study from our clinic demonstrated a possible link between cotrimoxazole-induced FDE and HLA-A30 antigen, in particular, the HLA-A30 B13 Cw6 haplotype (19). Additionally, as an interesting finding, HLA-B55 (split of B22) was exclusively positive in patients with cotrimoxazole-induced FDE (19). In the present study, HLA typing was performed in 9 children with cotrimoxazole-induced FDE. Five (55.6\%) of them were positive for complete haplotype (HLA-A30 B13 Cw6) or separate antigens (HLA-A30 or HLA-Cw6), supporting the proposed genetic basis. Moreover, 2 (22.2\%) children with cotrimoxazole-induced FDE were positive for HLA-B55 (split of B22) indicating that this antigen may also be associated with a drug other than feprazone, as previously reported (19).

In our pediatric cohort, only 1 patient had his first attack at the time of diagnosis, whereas 4 patients had more than 10 attacks. The disease duration before the diagnosis was 1 year or longer in nearly half (45.5\%) of the patients. Moreover, $36.4 \%$ of the patients were referred to our clinic with prior clinical diagnoses including herpes simplex infection, recurrent aphthous stomatitis/Behçet's disease, and purpura. These findings indicated that FDE may pose a diagnostic challenge in the pediatric population and is likely to be overlooked, underdiagnosed, or misdiagnosed, as previously suggested by many authors $(8,9)$.

The differential diagnosis of FDE is quite broad depending on the site of involvement (1). Lip lesions are commonly misdiagnosed as herpes simplex labialis, while mucosal (oral and genital) lesions may mimic the herpes simplex infection, aphthous stomatitis, Behçet's syndrome, erosive lichen planus, pemphigus vulgaris, erythema multiforme, and StevensJohnson syndrome (1). Skin lesions can imitate insect bite, pityriasis rosea, erythema annulare centrifugum, lichen planus, urticaria, erythema multiforme, Stevens-Johnson syndrome, toxic epidermal necrolysis, or graft-versus-host reaction $(1,3)$. Moreover, differentiation of FDE from symmetrical drug-related intertriginous and flexural exanthema (SDRIFE) may be difficult since site-specific recurrence is a common feature of both drug eruptions (20). Post-inflammatory pigmentation of the healed FDE lesions can resemble erythema dyschromicum perstans (1). Additionally, in children, FDE may also be misdiagnosed as child abuse (21).

Identification and avoidance of the culprit drugs as well as parent counseling and education are crucial to prevent further recurrences of FDE which may lead to unnecessary investigations, irrelevant treatments, and anxiety. Moreover, $54.5 \%$ of our pediatric patients reported an increase in the number and/or size of the lesions during subsequent attacks supporting the importance of early diagnosis of this unique drug eruption.
A high index of clinical suspicion accompanied by a comprehensive medication review is of paramount importance in diagnosing FDE. Considering its broad clinical spectrum in children, FDE should always be included in the differential diagnosis of any cutaneous and/or mucosal pediatric eruption with a waxing and waning course (2). Involvement of genitalia should be questioned in every patient as some children may be hesitant to mention genital lesions and associated symptoms including restlessness, pruritus, urinary retention, and painful micturition (9). In children, it is particularly important to question intermittent use of over-the-counter medications which may not be remembered by the parents (2). Moreover, recreational drug use, such as abuse of codeine-containing cough syrups, should be borne in mind as an increasing cause of FDE in adolescents $(2,22)$. As the most common causative agents of FDE change over time, as shown in our study, it is important to regularly update the list of the most frequent FDE inducers in children. Direct questioning and testing the suspected drugs according to these frequency lists and to the involved sites may aid in identifying the responsible agent, especially when it cannot be documented in a medication review (5).

The main limitation of this study was its retrospective design. Nevertheless, presenting the 24-year experience at a tertiary referral center in Turkey, the present study provides important insights into the characterization of FDE in children and thus, may be a significant contribution to the existing literature.

\section{CONCLUSION}

In conclusion, this study showed that FDE is a common type of drug eruption in the pediatric population. Clinical findings, drug-specific site involvement, and most common inducers of FDE in children seem to be largely similar to those in adults. Cotrimoxazole was the most common culprit before 2003, whereas NSAIDs, mainly used for the management of dysmenorrhea in adolescent girls, predominated thereafter. As a striking finding, phenobarbital in suppositories for fever was another important cause of pediatric $\mathrm{FDE}$, particularly involving the perioral area. The present study also demonstrated that FDE is likely to be overlooked, underdiagnosed, or misdiagnosed in children, as previously suggested by many authors. Therefore, further large studies focusing on the characteristic features of pediatric FDE are warranted to raise the awareness of this unique and lesser-known drug eruption among dermatologists and pediatricians.

Ethics Committee Approval: This study was approved by the Ethical Committee of Istanbul University, Istanbul Faculty of Medicine (approval number: 2021/93).

Informed Consent: Written or verbal consent was obtained from the participants.

Peer Review: Externally peer-reviewed.

Author Contributions: Conception/Design of Study- G.B.K., E.Ö.; Data Acquisition- G.B.K., E.Ö.; Data Analysis/Interpretation- G.B.K., E.Ö.; Drafting Manuscript- G.B.K., E.Ö.; Critical Revision of ManuscriptG.B.K., E.Ö.; Final Approval and Accountability- G.B.K., E.Ö. 
Conflict of Interest: Authors declared no conflict of interest.

Financial Disclosure: Authors declared no financial support.

Etik Komite Onayı: Bu çalışma İstanbul Üniversitesi İstanbul Tıp Fakültesi Etik Kurulu tarafindan onaylanmıştır (onay numarası: 2021/93).

Bilgilendirilmiş Onam: Katlımcılardan bilgilendirilmiş onam alınmıştır.

Hakem Değerlendirmesi: Dış bağımsız.

Yazar Katkıları: Çalışma Konsepti/Tasarım- G.B.K., E.Ö.; Veri ToplamaG.B.K., E.Ö.; Veri Analizi/Yorumlama- G.B.K., E.Ö.; Yazı Taslağı- G.B.K., E.Ö.; İçeriğin Eleştirel İncelemesi- G.B.K., E.Ö.; Son Onay ve SorumlulukG.B.K., E.Ö.

Çıkar Çatışması: Yazarlar çıkar çatı̧̧ması beyan etmemişlerdir.

Finansal Destek: Yazarlar finansal destek beyan etmemişlerdir.

\section{REFERENCES}

1. Özkaya E. Fixed drug eruption: state of the art. J Dtsch Dermatol Ges 2008;6(3):181-8.

2. Waldman R, Whitaker-Worth D, Grant-Kels JM. Cutaneous adverse drug reactions: Kids are not just little people. Clin Dermatol 2017;35(6):566-82.

3. Nguyen E, Gabel CK, Yu J. Pediatric drug eruptions. Clin Dermatol 2020;38(6):629-40.

4. Özkaya E. Changing trends in inducer drugs of fixed drug eruption: a 20-year cross-sectional study from Turkey. J Dtsch Dermatol Ges 2018;16(4):474-6.

5. Ozkaya-Bayazit E. Specific site involvement in fixed drug eruption. J Am Acad Dermatol 2003;49(6):1003-7.

6. Özkaya E. Oral mucosal fixed drug eruption: characteristics and differential diagnosis. J Am Acad Dermatol 2013;69(2):e51-8.

7. Kanwar AJ, Bharija SC, Belhaj MS. Fixed drug eruptions in children: a series of 23 cases with provocative tests. Dermatologica 1986;172(6):315-8.

8. Morelli JG, Tay YK, Rogers M, Halbert A, Krafchik B, Weston WL. Fixed drug eruptions in children. J Pediatr 1999;134(3):365-7.
9. Nussinovitch M, Prais D, Ben-Amitai D, Amir J, Volovitz B. Fixed drug eruption in the genital area in 15 boys. Pediatr Dermatol 2002;19(3):216-9.

10. Özkaya E, Kutlay A. Suppositories for fever as a major risk for phenobarbital-induced fixed drug eruption in children. J Eur Acad Dermatol Venereol 2017;31(10):e443-4.

11. Ozkaya-Bayazit E, Akar U. Fixed drug eruption induced by trimethoprim-sulfamethoxazole: evidence for a link to HLA-A30 B13 Cw6 haplotype. J Am Acad Dermatol 2001;45(5):712-7.

12. Khaled A, Kharfi M, Ben Hamida M, El Fekih N, El Aidli S, Zeglaoui $\mathrm{F}$, et al. Cutaneous adverse drug reactions in children. A series of 90 cases. Tunis Med 2012;90(1):45-50.

13. Sharma VK, Dhar S. Clinical pattern of cutaneous drug eruption among children and adolescents in north India. Pediatr Dermatol 1995;12(2):178-83.

14. Mahboob A, Haroon TS. Drugs causing fixed eruptions: a study of 450 cases. Int J Dermatol 1998;37(11):833-8.

15. Bharija SC, Singh M, Belhaj MS. Fixed drug eruption in an 8-monthold infant. Dermatologica 1988;176(2):108.

16. Dogra S, Handa S. Bullous necrotizing fixed drug eruption in an infant. Pediatr Dermatol 2004;21(3):281-2.

17. Pellicano R, Silvestris A, lannantuono M, Ciavarella G, Lomuto M. Familial occurrence of fixed drug eruptions. Acta Derm Venereol 1992;72(4):292-3.

18. Pellicano R, Ciavarella G, Lomuto M, Di Giorgio G. Genetic susceptibility to fixed drug eruption: evidence for a link with HLA-B22. J Am Acad Dermatol 1994;30(1):52-4.

19. Ozkaya-Bayazit E, Akar U. Fixed drug eruption induced by trimethoprim-sulfamethoxazole: evidence for a link to HLA-A30 B13 Cw6 haplotype. J Am Acad Dermatol 2001;45(5):712-7.

20. Ozkaya E, Babuna G. A challenging case: Symmetrical drug related intertriginous and flexural exanthem, fixed drug eruption, or both? Pediatr Dermatol 2011;28(6):711-4.

21. Mohamed KB. Fixed drug eruption associated with co-trimoxazole. J Pediatr 1999;135(3):396.

22. Agnich LE, Stogner JM, Miller BL, Marcum CD. Purple drank prevalence and characteristics of misusers of codeine cough syrup mixtures. Addict Behav 2013;38(9):2445-9. 